\title{
Model Penilaian Kemampuan Penalaran Proporsional pada Mahasiswa Calon Guru Anak Usia 6-7 Tahun
}

\author{
Rahmi Tasty Rosandi $^{1 凶}$, Yetti Supriyati $^{2}$, Elindra Yetti ${ }^{3}$ \\ Pendidikan Anak Usia Dini, Universitas Negeri Jakarta
}

\begin{abstract}
Abstrak
Penelitian ini bertujuan untuk mengembangkan produk penilaian yang digunakan untuk mengukur kemampuan penalaran proporsional mahasiswa calon guru anak usia 6-7 Tahun. Metode penelitian yang digunakan adalah penelitian pengembangan dengan model Borg and Gall, yang meliputi pengumpulan informasi, perencanaan, pengembangan produk awal, ujicoba one to one, revisi hasil ujicoba, ujicoba skala kecil dan ujicoba skala besar. Subjek penelitian ini adalah mahasiswa S1 PGSD yang dilakukan sebanyak tiga tahap ujicoba, yaitu uji coba one to one sebanyak 10 orang mahasiswa, uji coba kelompok kecil sebanyak 15 orang mahasiswa, dan uji coba kelompok besar sebanyak 30 orang mahasiswa. Teknik pengumpulan data dilakukan dengan angket dan dokumentasi. Teknik analisis data dalam penelitian ini adalah analisis data kualitatif dan analisis data kuantitatif. Hasil penelitian berdasarkan uji coba yang telah dilakukan serta dilihat dari tingkat kesukaran, reliabel dan kevalidan soal, maka diperoleh hasil akhir dari penggunaan produk penilaian sebesar $64,79 \%$. Dari hasil tersebut menunjukkan bahwa model yang dikembangkan menunjukkan interpretasi yang baik dan layak untuk diimplementasikan sebagai alat penilaian untuk mengukur kemampuan penalaran proporsional.
\end{abstract}

Kata kunci: kemampuan proporsional; penilaian; penelitian pengembangan.

\begin{abstract}
This study aims to develop assessment products that are used to measure the proportional reasoning abilities of students in early elementary school class candidates. The research method used is development research with the Borg and Gall model, which includes information gathering, planning, initial product development, one to one testing, revision of trial results, small-scale trials and large-scale trials. The subject of this research is PGSD S1 students conducted in three stages of testing, namely one to one trials as many as 8 students, small group trials of 15 students, and large group trials of 30 students. The technique of data collection is done by questionnaire and documentation. Data analysis techniques in this study are qualitative data analysis and quantitative data analysis. The results of the study are based on the trials that have been carried out and are seen from the level of difficulty, reliability and validity of the questions, so that the final results of the use of valuation products are obtained by $64.79 \%$. From these results indicate that the assessment developed shows good and feasible interpretation to be implemented as an assessment tool to measure proportional reasoning ability.
\end{abstract}

Keywords: proportional ability; assessment; development research

Copyright (c) 2019 Siska Perdina, Rien Safrina, Tjipto Sumadi

$\triangle$ Corresponding author :

Address : Jakarta, Indonesia

ISSN 2356-1327 (Media Cetak)

Email : rahmitasty@gmail.com

ISSN 2549-8959 (Media Online) 


\section{PENDAHULUAN}

Pendidikan merupakan salah satu upaya untuk dapat meningkatkan sumber daya manusia. Sekolah sebagai satuan pendidikan formal yang mengemban tugas untuk dapat menyiapkan siswa untuk menghadapi lingkungan hidup yang terus mengalami perubahan yang sangat pesat, mampu bersaing dikehidupan dan dapat menyesuaikan diri terhadap tantangan yang semakin besar. Untuk itu perlu adanya usaha memberikan pendidikan dan pengajaran yang tepat bagi anak, khususnya anak usia dini.

Pendidikan anak usia dini merupakan bagian dari pendidikan yang mempunyai tanggung jawab yang besar, karena pada masa ini anak-anak membentuk keterampilan dan mengembangkan kemampuan yang dimilikinya dengan pesat. Berbagai macam pendidikan yang ada dibutuhkan untuk membangun dan mengembangkan kognitif anak, salah satunya melalui pendidikan mengenai sains dimana masa anak ke depannya, kehidupan anak tidak akan terhindar dari sains. Anak dapat memahami gejala fenomena yang terjadi di sekitarnya, mengetahui sebab dan akibat mengenai sesuatu dan juga dibutuhkan pola berfikir matematika untuk berbagai macam kegiatan seperti berbelanja, membuat sesuatu, dan sebagainya. Untuk dapat mengembangkan pendidikan anak mengenai sains yang diharapkan dibutuhkan sosok yang mengerti akan pendidikan tersebut, seperti dosen yang mengajarkan pendidikan sains kepada mahasiswa calon guru, serta mahasiswa calon guru anak usia 6-7 tahun yang nantinya akan mengemban tugas untuk mendidik anak usia dini.

Bagi seorang dosen ataupun calon pendidik perlu adanya penguasaan materi dan konsep yang matang guna menunjang tingkat keberhasilan dalam penyampaian informasi kepada pihak lain. Calon guru harus memiliki kemampuan yang baik dalam mengembangkan kreativitas. Menjadi seorang tenaga pendidik yang profesional merupakan beban tugas mulya yang sangat penting, karena dengan kepiawaian seorang tenaga pendidik dalam menyajikan dan mentransferkan ilmu kepada pihak lain, diharapkan ilmu tersebut dapat diterima dan diserap dengan baik. Salah satu kemampuan seorang calon pendidik yaitu harus dapat menciptakan kondisi lingkungan belajar yang kondusif. Adapun kemampuan ini juga tertuang dalam Peraturan Menteri Pendidikan Nasional No. 16 Tahun 2007 tentang Standar Kualifikasi Akademik dan Kompetensi Guru, yaitu diantaranya seorang guru atau calon pendidik harus memiliki kompetensi kepribadian, kompetensi pedagogik, kompetensi profesional, dan kompetensi sosial (Setiawan, 2018).

Sehubungan dengan masalah tersebut, terdapat beberapa penelitian mengenai penalaran formal, khususnya mengenai penalaran proporsional. Penelitian pertama dilakukan oleh Stephen ditemukan hasil bahwa banyak ditemukannya siswa yang dapat menerapkan pendekatan numerik tetapi tidak dapat menerapkan struktur perkalian yang terkait dengan penalaran proporsional (Norton, 2005). Setiap orang akan dihadapkan dengan kecepatan, kepadatan, jarak tempuh suatu bensin mobil, dan berbagai satuan angka.

Penelitian kedua yang dilakukan oleh Lay Yoon Fah yang berjudul Logical Thinking Abilities among Form 4 Students in the Interior Division of Sabah Malaysia menemukan hasil bahwa kemampuan ratarata berfikir logis siswa masih rendah, dengan skor rata-rata persentase untuk semua penalaran lebih rendah dari rata-rata keseluruhan. Selain itu penelitian ini juga mengungkapkan bahwa terdapat $98 \%$ responden berada di tahap operasional 
konkret sedangkan $2 \%$ lainnya dikategorikan di tahap transisi. Selanjutnya juga ditemukan bahwa tidak ada perbedaan yang signifikan untuk kemampuan berfikir seseorang berdasarkan jenis kelaminnya (Fah, 2009). Konsep rasio dan perbandingan diterapkan secara luas dalam matematika, sains dan setiap kehidupan. Penalaran proporsional juga digunakan dalam membaca peta, membuat perkiraan jarak menggunakan skala pada peta.

Hasil penelitian ketiga yang dilakukan oleh Lesh, Post dan Behr ditemukan bahwa karakteristik penting dari penalaran proporsional yaitu dengan melibatkan penalaran tentang hubungan holistik antara dua ekspresi rasional seperti tarif, rasio, perbandingan dan fraksi (Lesh, R., Post, T., dan Behr, 1988). Penelitian keempat mengenai sains yang dilakukan oleh Nancy dengan judul Engaging ypung children in science and mathematics ditemukan bahwa dalam mengembangkan pembelajaran sains dan matematika perlu adanya rancangan dalam pengalaman belajar yang difokuskan pada domain kognitif dan afektif anak. Selain itu perlu adanya berbagai macam metode pengajaran yang dapat diberikan karena siswa memiliki beragam kemampuan yang berbeda-beda (Gallenstein, 2005).

Hasil penelitian kelima yang dilakukan oleh Kathrin dan Peter yang berjudul Beginning students may be less capable of proportional reasoning than they appear to be ditemukan bahwa masih banyaknya siswa yang cukup mengalami kesulitan dalam menerapkan penalaran proporsional mengenai rasio atau produk dari dua kuantitas varian, yaitu jumlah yang sebanding ataupun berbanding terbalik dengan satu dan lainnya (Glaser \& Peter, 2015). Penelitian selanjutnya yang dilakukan oleh Caneida dengan judul Effect of Number Structure and Nature of Quantities on Secondary School Students
Proportional Reasoning yang dilakukan pada siswa di sekolah menengah menunjukkan hasil bahwa struktur angka mempengaruhi kinerja siswa dan berbagai strategi yang berbeda digunakan untuk memecahkan masalah yang ada (Ceneida Fernandez, Salvador Llinares, Wim, Vandooren, Dirk De Bock, 2011).

Penelitian ini mengembangkan produk penilaian baru yang berbeda dari penelitian diatas untuk mengukur kemampuan penalaran proporsional mahasiswa calon guru anak usia 6- 7 tahun dalam mata kuliah konsep dasar biologi. Penilaian ini dibuat agar dapat mengetahui kemampuan mahasiswa sejauh mana dalam memahami konsep penalaran proporsional yang mana berguna untuk mengajarkan sains pada anak didiknya.

Berdasarkan hasil observasi yang dilakukan di lapangan, ditemukan bahwa penilaian yang dilakukan masih terpaku melalui proses penugasan, ujian tengah semester, ujian akhir semester dan tugastugas maupun praktek yang dilakukan mahasiswa. Sebagai seorang mahasiswa calon guru sekolah dasar awal yang nantinya akan terjun ke dunia PAUD dalam mengajar anak-anak usia dini, tentu diharapkan memiliki kemampuan penalaran proporsional yang baik pula dimana mahasiswa calon guru sekolah dasar awal dituntut memahami dalam variasi dan perbandingan serta memahami pengukuran besaran dengan menggunakan alat-alat ukur yang akan berguna dalam praktek kegiatan pada anak usia dini, khususnya mengenai sains. Berdasarkan uraian mengenai penelitian yang telah dilakukan oleh sejumlah peneliti, menunjukkan belum ada penelitian yang membuat penilaian khusus yang dapat mengukur penalaran proporsional mahasiswa calon guru sekolah dasar awal. Sehubungan dengan hal tersebut peneliti mengembangkan model penilaian yang dapat mengukur kemampuan 
penalaran proporsional mahasiswa calon guru sekolah dasar awal.

Penilaian merupakan komponen yang penting dalam suatu penyelenggaraan pendidikan. Meningkatkan kualitas pendidikan dapat ditempuh dengan meningkatkan kualitas pembelajaran dan kualitas sistem penilaiannya dimana kedua tersebut saling terkait. Sistem pembelajaran yang baik akan menghasilkan kualitas belajar yang baik pula dimana kualitas pembelajaran tersebut dapat dilihat dari hasil penilaiannya. Selanjutkan sistem penialaian yang baik akan mendorong pendidik untuk dapat menentukan strategi pembelajaran yang baik dan dapat memotivasi peserta didik agar belajar lebih baik.

Seperti yang telah diuraikan di atas, penilaian mencakup semua cara yang digunakan untuk menilai unjuk kerja individu. Adapun proses penilaian menurut Mardapi meliputi pengumpulan bukti-bukti mengenai hasil belajar peserta didik, dimana bukti ini tidak hanya diperoleh melalui tes saja, tetapi bisa dikumpulkan melalui pengamatan atau laporan diri. Penilaian memerlukan data yang baik mutunya sehingga perlu didukung oleh proses pengukuran yang baik (Mardapi, 2007).

Istilah penilaian merupakan alih bahasa dari istilah assessment. Depdikbud mengemukakan penilaian adalah suatu kegiatan untuk memberikan berbagai informasi secara berkesinambungan dan menyeluruh tentang proses dan hasil yang telah dicapai siswa. Gronlund mengartikan penilaian adalah suatu proses yang sistematis dari pengumpulan, analisis, dan interprestasi informasi atau data untuk menentukan sejauh mana peserta didik telah mencapai tujuan pembelajaran (Arifin, 2011). Sementara itu Anthony J. Nitko dalam Zainal Arifin menjelaskan "assessment is a broad term defined as a process for obtaining information that is used for making decisions about students...". Penilaian harus dipandang sebagai salah satu faktor penting yang menentukan keberhasilan proses dan belajar, bukan hanya cara yang digunakan untuk menilai hasil belajar (Arifin, 2011). Kegiatan penilaian harus dapat menginformasikan guru mengenai peningkatan kemampuan mengajarnya dan membantu peserta didik mencapai perkembangan belajarnya secara optimal.

Menurut Chittenden dalam Djemari Mardapi, kegiatan penilaian dalam proses pembelajaran perlu diarahkan pada empat hal, yaitu (1) penelusuran, yaitu kegiatan yang dilakukan untuk menelusuri apakah proses pembelajaran telah berlangsung sesuai yang direncanakan atau tidak; (2) pengecekan, yaitu untuk mencari informasi apakah terdapat kekurangan-kekurangan pada peserta didik selama proses pembelajaran; (3) pencarian, yaitu untuk mencari dan menemukan penyebab kekurangan yang muncul selama proses pembelajaran berlangsung; dan kesimpulan, yaitu untuk menyimpulkan tentang tingkat pencapaian belajar yang telah dimiliki peserta didik. Data untuk kepentingan penilaian diperoleh dengan menggunakan alat ukur, dimana alat ukur yang banyak digunakan dalam penilaian pendidikan adalah tes (Mardapi, 2007).

Berdasarakan pengertian penilaian menurut para ahli diatas, dapat disimpulkan bahwa penilaian adalah penggunaan berbagai cara secara berkala, berkesinambungan dan menyeluruh untuk memperoleh informasi mengenai sejauh mana hasil belajar yang telah dicapai oleh peserta didik dimana hasil penilaian dapat berupa nilai kualitatif (pernyataan naratif berupa kata-kata) maupun nilai kuantitatif (angka). 
Teori perkembangan kognitif Piaget adalah salah satu teori yang menjelaskan bagaimana anak beradaptasi dengan dan menginterprestasikan objek dan kejadiankejadian di sekitarnya. Piaget memandang bahwa anak memainkan peran aktif di dalam menyusun pengetahuannya mengenai realitas. Anak tidak pasif menerima informasi. Desmita mengungkapkan menurut Hetherington \& Parke walaupun proses berfikir dan konsepsi anak mengenai realitas telah dimodifikasi oleh pengalamannya dengan dunia disekitarnya, anak juga berperan aktif dalam menginterpretasikan informasi yang ia peroleh dari pengalaman serta dalam mengadaptasikannya pada pengetahuan dan konsepsi mengenai dunia yang telah ia miliki (Desmita, 2007).

Jamaris mengatakan bahwa Piaget membagi perkembangan kognitif ke dalam empat fase, yaitu fase sensorimotor (usia 02 tahun), fase praoperasional (usia 2-7 tahun), fase operasional konkret (usia 7-12 tahun) dan fase operasi formal (12 tahun sampai usia dewasa). Adapun keempat fase tersebut tersusun secara hierarkis, yaitu seseorang tidak akan dapat memasuki fase tahapan operasi formal sebelum fase sensorimotor dan praoperasional dilampaui (Jamaris, 2006).

Fase operasional formal ditandai oleh perpindahan dari cara berfikir konkret ke abstrak. Kemampuan berfikir abstrak dapat dilihat dari kemampuan mengemukakan ide-ide, memprediksi kejadian yang akan terjadi, dan melakukan proses berfikir ilmiah yaitu mengemukakan hipotesis dan menentukan cara untuk membuktikan kebenaran hipotesis tersebut. Berdasarkan teori perkembangan koginitif yang diusulkan oleh jean Piaget, anak usia 12 tahun keatas berada pada tahap operasional formal yang mana pada masa itu anak sudah dapat berfikir logis tentang proposisi abstrak dan uji hipotesis. Seperti halnya yang dikatakan oleh Wilson dalam Yoon Lay Fah, penalaran operasional formal merupakan penentu keberhasilan siswa dalam sains dan matematika pada jenjang berikutnya. Kelemahan siswa dalam mengembangkan daya nalar ikut berimbas pada kemampuan pemecahan masalah. Piaget menyatakan bahwa siswa dianggap siap mengembangkan konsep atau materi khusus jika memperoleh skema yang diperlukan. Artinya proses belajar mengajar akan menjadi terhambat bila penalaran formal siswa tidak sesuai dengan yang diharapkan dan diperlukan (Fah, 2009).

Perkembangan ilmu pengetahuan yang begitu pesat memacu guru dan para pendidik untuk menyiapkan mahasiswa agar siap bersaing dalam kehidupan global. Keterampilan dalam memecahkan masalah adalah poin utama dalam kehidupan, selain itu melalui pemecahan masalah mahasiswa akan terlatih dan terdorong untuk mengembangkan penalaran formalnya secara mandiri.

Menurut Dahar, ada lima operasi penalaran yaitu penalaran proporsional, pengontrolan variabel, penalaran probabilistik, penalaran korelasional dan penalaran kombinatorial. Sedangkan menurut flavell ada empat karakteristik dari berfikir operasional formal, pertama yaitu berfikir adolensensi ialah hipotesisdeduktif. Seseorang dapat merumuskan alternatif hipotesis yang banyak dalam menanggapi masalah dan mengecek data terhadap setiap hipotesis untuk membuat suatu keputusan yang layak, namun belum memiliki kemampuan untuk menerima atau menolak hipotesis. Kedua, yaitu berfikir proporsional, dalam berfikir suatu anak yang berada di tahapan operasional formal tidak akan merasa terbatasi dengan benda ataupun peristiwa yang konkret saja, tapi juga dapat menangani proposisi yang berlawanan dengan fakta. Ketiga yaitu berfikir kombinatorial yaitu berfikir 
meliputi semua kombinasi benda, gagasan atau proposisi yang memungkinkan. Dan yang terakhir yaitu berfikir reflektif, seorang anak yang berada pada periode ini dapat berfikir seperti orang dewasa, dan dapat berfikir kembali mengenai apa yang telah dilakukan atau yang telah dikerjakannya (Dahar, 2011).

Van de Walle dalam Arvyaty dan Cipto mengatakan bahwa bagian dari penalaran proporsional adalah kemampuan mengenali rasio dalam berbagai situasi (Arvyati, n.d.). Hal ini dipertegas juga oleh Nur yang mendefinisikan penalaran proporsional sebagai suatu struktur kualitatif yang memungkinkan pemahaman sistem-sistem fisik kompleks yang mengandung banyak faktor (Nur \& Rahman, 2013). Yang termasuk dalam sistem fisik ini misalnya konsep tentang rasio dan proporsi. Konsep rasio dan perbandingan diterapkan secara luas dalam matematika, sains dan setiap kehidupan. Penalaran proporsional juga digunakan dalam membaca peta, membuat perkiraan jarak menggunakan skala pada peta. Seperti halnya yang dikemukakan oleh Wilson dalam Lay Yoon Fah (2009), penalaran proporsional merupakan penentu keberhasilan siswa dalam sains dan matematika pada tahap selanjutnya dalam menjalani kehidupan. Nickerson dalam Nur juga mengemukakan bahwa anak yang mampu menalar proporsional dapat mengembangkan hubungan proporsional berat dan volume, mentransfer penalaran proporsional dari dua dimensi ketiga dimensi, menggunakan penalaran proporsional untuk menaksir ukuran suatu proporsional satu populasi yang tidak diketahui. Lesh, Post dan Behr mendefinisikan penalaran proporsional sebagai berikut:

"Proportional reasoning is a form of mathematical reasoning that involves a sense of co-variation and of multiple comparisons, and the abality to mentally store and process several pieces of information. Proportional reasoning is very much concerned with inference and prediction and involves both qualitative and quantitative methods of thought".

Pernyataan tersebut memiliki makna yaitu penalaran proporsional adalah bentuk penalaran matematika yang melibatkan pemahaman tentang kovariasi dan berbagai perbandingan, serta kemampuan secara mental untuk menyimpan dan memproses beberapa informasi. Penalaran proporsional sangat terkait dengan kesimpulan dan prediksi dan melibatkan kedua metode berfikir kualitatif dan kuantitatif (Lesh, R., Post, T., dan Behr, 1988).

Berdasarkan pendapat di atas, maka siswa yang telah tergolong tahap operasional formal akan dapat memahami dan menjawab dengan benar soal-soal yang berkaitan dengan masalah proposisi dan rasio, meskipun mereka belum mempelajarinya. Dengan kata lain dapat dinyatakan bahwa siswa yang telah memasuki operasi formal akan mempunyai kemampuan penalaran proporsional. Penalaran proporsional telah dikaji oleh para peneliti dan menyepakati bahwa penalaran proporsional merupakan konsep penting bagi mahasiswa. Mahasiswa harus selalu melibatkan penalaran proporsional dalam proses pemecahan masalah. Untuk dapat meningkatkan kemampuan penalaran proporsional mahasiswa, kemampuan memecahkan masalah terlebih dahulu harus dibangkitkan.

Adapun keempat penalaran yang terdiri dari hipotesis deduktif, proporsional, kombinatorial maupun reflektif merupakan suatu penguat seseorang saat berada di tahapan operasional formal, karena di periode ini akan sangat menentukan dan membantunya dalam kehidupan di era 
modern di masa yang akan datang, dan dapat membantu seseorang dalam menjalani suatu kehidupan.

Seseorang yang mampu berfikir secara proporsional memiliki beberapa karakteristik, adapun karakteristik dari pemikir proporsional adalah sebagai berikut: 1) memiliki pemahaman tentang kovariasi, dimana dapat memahami hubungan dua kuantitas yang mempunyai variasi yang sama dan dapat melihat kesesuaian antara dua variasi yang berbeda; 2) mampu mengenali hubungan proporsional dan non proporsional dalam dunia nyata; 3) mampu mengembangkan banyak strategi untuk menyelesaikan masalah proporsi; 4) mampu memahami rasio sebagai entitas tersendiri yang menyatakan hubungan yang berbeda antar kuantitas-kuantitas yang dibandingkan.

Menurut Lamon dalan John a Walle, diperkirakan lebih dari setengah populasi orang dewasa tidak dapat danggap sebagai pemikir proporsional. Hal ini berarti dengan bertambahnya usia kita, belum tentu kita dapat menguasai kebiasaan dan keterampilan proporsional. Pengajaran yang diberikan dapat memberikan pengaruh, terutama jika aturan dan logaritma untuk perhitungan pecahan, untuk membandingkan rasio, dan untuk menyelesaikan proporsi ditunda terlebih dahulu. Seorang anak harus diberikan waktu yang cukup dalam memahami sesuatu, sebelum memasuki ke tahapan pembelajaran selanjutnya (Walle, 2008).

Berdasarkan pengertian kemampuan penalaran proporsional menurut para ahli di atas, maka dapat disimpulkan bahwa kemampuan penalaran proporsional adalah kemampuan tahapan berfikir lebih mendalam yang berada di tahapan operasional formal, dimana pada penalaran ini seseorang memiliki kemampuan dalam menjawab dan memahami suatu masalah yang berkaitan dengan proporsi dan rasio dengan aspek (1) memahami berbagai variasi; (2) memahami perbandingan; (3) memiliki kemampuan dalam memproporsikan sesuatu serta; (4) dapat menggunakan rasionalnya.

\section{METODOLOGI}

Penelitian ini menggunakan metode penelitian dan pengembangan ( $R \& D$ ). Desain penelitian yang digunakan adalah model Borg an Gall Gall. Subjek dalam penelitian ini adalah Mahasiswa Jurusan Pendidikan Guru Sekolah Dasar yang telah mengikuti perkuliahan mata kuliah Konsep Dasar Biologi. Hal ini disesuaikan dengan tujuan penelitian itu sendiri yaitu mengembangkan penilaian mata kuliah Konsep Dasar Biologi untuk mengukur Kemampuan Penalaran Proporsional.

Teknik pengumpulan data berupa observasi, wawancara dan angket. Teknik analisis data yang dilakukan dalam penelitian ini yaitu teknik analisis data kualitatif dan teknik analisis data kuantitatif. Data kuantitatif diperoleh dari hasil skor angket subjek penelitian. Sedangkan data kualitatif diperoleh dari tanggapan para ahli dan subjek penelitian. Data yang diperoleh dari validasi uji kelayakan ahli dan dari uji kelayakan (baik dari uji coba perorangan sebanyak 10 orang, kelompok kecil sebanyak 15 orang, dan uji lapangan atau kelompok besar sebanyak 30 orang) yang dianalisis dengan cara menghitung nilai berdasarkan skala penilaian yang telah ditentukan. Skala yang akan digunakan adalah Skala Likert dengan nilai maksimal adalah empat.

\section{HASIL DAN PEMBAHASAN Validasi Teoritik}

Validasi teoritik dilakukan dengan meminta penilaian dan masukan dari beberapa expert judgement (para ahli) dalam mengembangkan dan memperbaiki 
kualitas dari produk model yang dikembangkan oleh peneliti yaitu model penilaian mata kuliah Konsep Biologi Dasar untuk mengukur penalaran proporsional mahasiswa calon guru anak usia 6-7 Tahun di UNJ. Para ahli yang diminta untuk menguji kelayakan model memiliki latar bekalang keahlian dalam bidang desain dan materi yang tepat bagi mahasiswa.

\section{Pakar Materi}

Validasi uji kelayakan materi biologi memiliki dua aspek penilaian yaitu kesesuaian materi dan kesesuaian kemampuan peserta didik. Adapun hasil dari validasi ditinjau dari segi kesesuaian materi sebesar 4,6\% dan kesesuaian kemampuan peserta didik sebesar $4 \%$ serta validasi keseluruhan aspek sebesar 4,43\%. Hal ini menunjukkan bahwa soal yang ditinjau dari kedua segi aspek tersebut memiliki interpretasi sangat baik dan produk penilaian yang dikembangkan layak digunakan sebagai penilaian kemampuan penalaran proporsional mahasiswa dalam pembelajaran konsep dasar biologi.

Validasi uji kelayakan materi biologi yang kedua juga memiliki dua aspek penilaian yaitu kesesuaian materi dan kesesuaian kemampuan peserta didik. Adapun hasil dari validasi ditinjau dari segi kesesuaian materi sebesar $4,8 \%$ dan kesesuaian kemampuan peserta didik sebesar 4\% serta validasi keseluruhan aspek sebesar $4,57 \%$. Hal ini menunjukkan bahwa soal yang ditinjau dari kedua segi aspek tersebut memiliki interpretasi sangat baik dan produk penilaian yang dikembangkan layak digunakan sebagai penilaian kemampuan penalaran proporsional mahasiswa dalam pembelajaran konsep dasar biologi.
Pakar Bahasa

Validasi uji kelayakan bahasa memiliki dua aspek penilaian yaitu kelayakan bahasa dan kelayakan penyajian. Adapun hasil dari validasi ditinjau dari segi kelayakan bahasa sebesar 4,2\% dan kelayakan penyajian sebesar $4,5 \%$ serta validasi keseluruhan aspek sebesar 4,33\%. Hal ini menunjukkan bahwa soal yang ditinjau dari kedua segi aspek tersebut memiliki interpretasi sangat baik dan produk instrumen yang dikembangkan layak digunakan sebabagai penilaian kemampuan penalaran proporsional mahasiswa dalam pembelajaran konsep dasar biologi.

\section{Validasi Empiris}

Uji coba one to one

Uji coba one to one pada penelitian ini menggunakan jumlah siswa sebanyak 10 orang. Dimana mahasiswa dipilih secara acak yang sedang maupun yang telah mengikuti perkuliahan mata kuliah konsep dasar biologi. Setelah melakukan uji coba, mahasiswa memberikan masukan-masukan mengenai produk penilaian yang telah peneliti kembangkan, adapun komentar dan masukan yang diberikan berupa adanya kalimat yang kurang dipahami serta ada beberapa pertanyaan yang mereka kesulitan untuk menjawabnya.

Dalam melakukan uji coba produk one to one diperoleh data rata-rata persentase penilaian seluruh aspek adalah $66,89 \%$ dan jawaban butir soal mahasiswa peroleh adalah $62,5 \%$. Hal ini menunjukkan bahwa model yang dikembangkan oleh peneliti memiliki interpretasi yang baik dan penalaran proporsional mahasiswa dinyatakan rata-rata baik. Dari hasil validasi dan uji coba yang telah dilakukan menunjukkan bahwa bahwa produk penilaian tersebut layak untuk diimplementasikan sebagai alat penilaian kemampuan penalaran proporsional 
mahasiswa dalam mata kuliah konsep dasar biologi. Sebelum melakukan ujicoba kelompok kecil dan ujicoba lapangan skala besar maka perlu dilakukan berbagai macam revisi baik berupa masukan dari beberapa para ahli (expert judgement) maupun mahasiswa.

\section{Uji coba kelompok kecil}

Setelah melakukan ujicoba one to one, maka langkah selanjutnya yaitu merevisi produk yang akan digunakan. Setelah Draf I selesai, maka dapat dilakukan ujicoba pada kelompok kecil, hal ini dilakukan guna melihat dan mengidentifikasi kekurangan-kekurangan yang terdapat dalam produk model yang dikembangkan. Revisi yang dilakukan telah melalui proses expert judgement oleh 3 orang ahli, masing-masing 2 orang pada ahli materi biologi, dan 1 orang pada ahli bahasa. Ujicoba yang dilakukan pada kelompok kecil ini yaitu melibatkan 15 orang mahasiswa, yang dipilih secara random yang sedang mengikuti mata kuliah konsep dasar biologi maupun yang telah menyelesaikan mata kuliah tersebut. Dari rekapitulasi data yang dilakukan ditemukan hasil sebagai berikut:

Tabel 4.8 Hasil Uji Coba Lapangan Kelompok Kecil

\begin{tabular}{llll}
\hline No & $\begin{array}{l}\text { Aspek } \\
\text { Penilaian }\end{array}$ & $\begin{array}{l}\text { Presentasi } \\
\text { Keseluruhan }\end{array}$ & $\begin{array}{l}\text { Interpres } \\
\text { tasi }\end{array}$ \\
\hline $\mathbf{1}$ & Variasi & 71,66667 & Baik \\
$\mathbf{2}$ & Perbandingan & 74,1667 & Baik \\
$\mathbf{3}$ & Proporsi & 74,1667 & Baik \\
$\mathbf{4}$ & Rasional & 29,1667 & $\begin{array}{l}\text { Kurang } \\
\text { Baik }\end{array}$ \\
\hline \multicolumn{3}{c}{} & Baik \\
\hline Rata-rata & $\mathbf{6 2 , 2 9 1 7}$ \\
\multicolumn{5}{c}{ Keterangan: } \\
$81 \%-100 \%$ & $=$ Sangat Baik \\
$61 \%-80 \%$ & $=$ Baik \\
$41 \%-60 \%$ & $=$ Sedang \\
$21 \%-40 \%$ & $=$ Tidak Baik \\
$0-25 \%$ & $=$ Sangat Tidak Baik
\end{tabular}

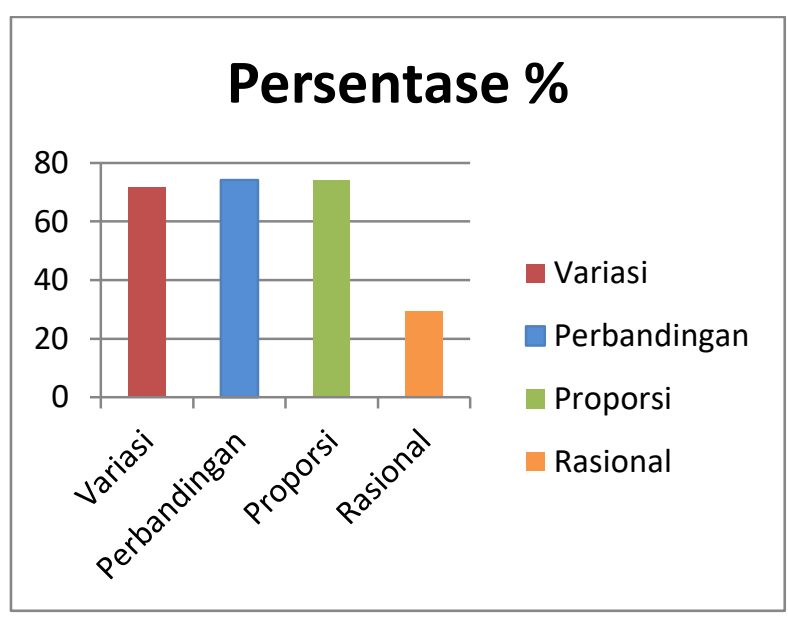

Gambar 4.2 Diagram Batang Persentase

Aspek Proporsional Kelompok Kecil

Dari hasil ujicoba kelompok kecil sebanyak 15 orang di atas diperoleh hasil rata-rata persentase penilaian seluruh aspek sebesar $62,29 \%$ yang berarti bahwa produk penilaian yang dikembangkan memiliki interpretasi yang baik dan layak untuk diimplementasikan sebagai alat penilaian dalam mengukur kemampuan penalaran proporsional mahasiswa.

\section{Uji coba kelompok besar}

Uji coba kelompok besar dapat diuji cobakan kepada mahasiswa setelah dilakukan revisi kembali terhadap produk model yang dikembangkan berdasarkan masukan-masukan oleh expert judgement dan mahasiswa. Dari hasil ujicoba yang dilakukan oleh mahasiswa sebanyak 30 orang tersebut diperoleh hasil sebagai berikut:

Tabel 4.9 Hasil Uji Coba Kelompok Besar

\begin{tabular}{llll}
\hline No & $\begin{array}{l}\text { Aspek } \\
\text { Penilaian }\end{array}$ & $\begin{array}{l}\text { Presentasi } \\
\text { Keseluruhan }\end{array}$ & Interprestasi \\
\hline $\mathbf{1}$ & Variasi & 88,3333 & Sangat Baik \\
$\mathbf{2}$ & Perbandinga & 38,3333 & Kurang Baik \\
& n & & \\
$\mathbf{3}$ & Proporsi & 71,25 & Baik \\
$\mathbf{4}$ & Rasional & 61,25 & Baik \\
\hline Rata-rata & $\mathbf{6 4 , 7 9 1 7}$ & Baik \\
\hline
\end{tabular}


Keterangan:

$81 \%-100 \%=$ Sangat Baik

$61 \%-80 \%=$ Baik

$41 \%-60 \%=$ Sedang

$21 \%-40 \%=$ Tidak Baik

$0-25 \%=$ Sangat Tidak Baik

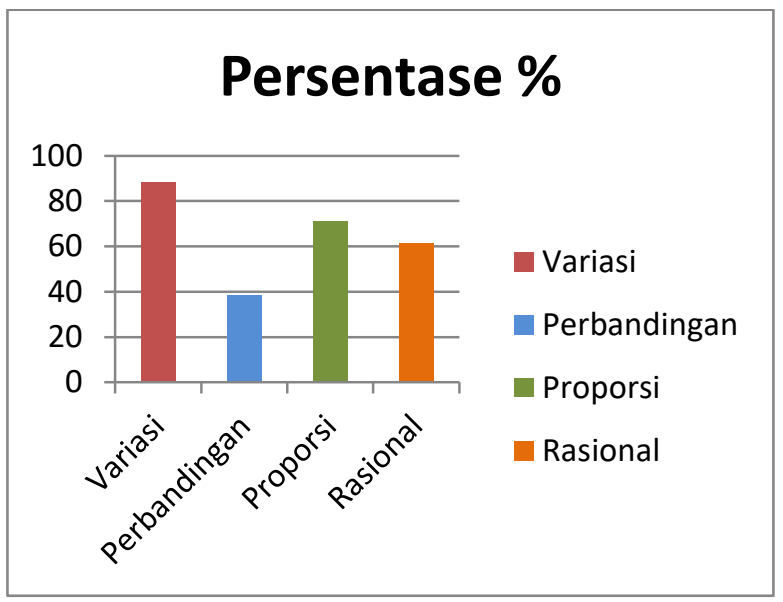

Gambar 4.3 Diagram Batang Persentase Aspek Proporsional Kelompok Besar

Dari hasil ujicoba kelompok besar sebanyak 30 orang di atas diperoleh hasil rata-rata persentase penilaian seluruh aspek sebesar $64,79 \%$ yang berarti bahwa produk penilaian yang dikembangkan memiliki interpretasi yang baik dan layak untuk diimplementasikan sebagai alat penilaian dalam mengukur kemampuan penalaran proporsional mahasiswa pada mata kuliah konsep dasar biologi.

\section{PEMBAHASAN}

Penelitian pengembangan produk penilaian ini dilakukan pada mahasiswa calon guru anak usia 6-7 tahun yang telah mengikuti maupun yang sedang mengambil mata kuliah konsep dasar biologi. Penelitian dan pengembangan ini bertujuan untuk menghasilkan model penilaian kemampuan penalaran proporsional yang dapat digunakan pada calon guru yang akan mengajar nantinya, khususnya yang akan mengajar di kelas awal. Berdasarkan hasil uji coba yang telah melalui proses pengujian kevalidan, tingkat kesukaran serta kereliabelan soal diperoleh hasil akhir sebanyak $62,29 \%$ dimana hal ini menunjukan bahwa produk penilaian yang dikembangkan menunjukkan interprestasi yang baik sehingga layak untuk diimplementasikan sebagai alat untuk mengukur kemampuan penalaran proporsional mahasiswa calon guru sekolah dasar awal. Penelitian yang dilakukan oleh Annette, Geoff, Shelley dan Merrylyn dengan judul Promoting middle school students proportional reasoning skills through an ongoing professional development programme for teachers menjelaskan bahwa penalaran proporsional dalam hal menggunakan rasio dalam situasi yang melibatkan perbandingan jumlah sangat penting untuk kompetensi matematika, terutama di tahun sekolah menengah dan merupakan penentu penting keberhasilan di luar sekolah. Penalaran proporsional tidak selalu berkembang secara alami, namun dari beberapa penelitian menunjukkan bahwa dengan pengajaran yang ditargetkan, kemampuan penalaran proporsional dapat dikembangkan (Hilton, Hilton, Dole, \& Hilton, 2016).

Semakin berkembangnya zaman, manusia dituntut untuk dapat lebih produktif dan lebih kreatif. Tidak terlepas dari peran seorang guru atau calon pendidik harus dapat menguasai materi dan menyesuaikan keadaan dengan lingkungan disekitarnya. Hal ini sejalan dengan hasil penelitian yang dilakukan oleh David, James, William dan Catherin menunjukkan bahwa siswa dalam kurikulum reformasi yang didorong untuk membangun pengetahuan konseptual dan prosedural secara proporsional melalui kegiatan pemecahan masalah kolaboratif berkinerja lebih baik daripada siswa dengan pengalaman instruksional yang lebih tradisional dan diarahkan guru. Siswa yang telah mempelajari kurikulum baru, mampu 
mengembangkan kemampuan mereka untuk dapat menemukan solusi dari suatu permasalahan dan bersifat kreatif (David benchaem, James T. Fey, William M. Fitzgerald, Catherine Benedetto, 1998).'

Model penilaian kemampuan penalaran proporsional dikembangkan dari kisi-kisi yang diterangkan oleh ahli serta disesuaikan dengan silabus mata kuliah konsep dasar biologi yang ada di Universitas. Adapun sebelum mengembangkan model penelitian tersebut, peneliti melakukan survey di awal untuk mengetahui keadaan disekitar objek yang akan diteliti. Setelah mendapatkan gambaran, model dikembangkan melalui literatur-literatur yang tersedia, serta melakukan kolaborasi dengan para ahli untuk membantu mendapatkan model penilaian yang diharapkan.

Calon pendidik dituntut untuk dapat memiliki kemampuan dalam mengembangkan kreativitasnya, dalam proses tersebut, tentunya mahasiswa calon guru sekolah dasar awal calon guru harus berani menemukan solusi dan memiliki kepercayaan diri dalam menyelesaikan setiap persoalan yang dihadapi. Hal ini sejalan dengan penelitian yang dilakukan oleh Kingston dan Fiona ditemukan bahwa kepercayaan diri dan memori kerja berpengaruh terhadap penalaran proporsional. Analisis korelasional juga menemukan bahwa adanya perbedaan jenis kelamin dalam hubungan antara kepercayaan diri dan penalaran proporsional (Kingston \& Lyddy, 2013).

Agar guru sekolah dapat membantu siswa mereka menjadi pemikir proporsional, mereka harus memahami karakteristik dari penalaran proporsional tersebut berkembang, muncul secara bertahap dan tumbuh dalam rentang beberapa tahun. Penelitian yang dilakukan oleh Thompson dan William (2003) menerangkan bahwa guru sekolah menengah di Kentucky dapat meningkatkan keterampilan penalaran proporsional mereka sendiri, mereka belajar banyak mengenai pemikiran siswa, dan mereka belajar aplikasi penting yang memerlukan penalaran proporsional. Selain itu menunjukkan bahwa adanya kemampuan dari siswa dalam mencari jawaban dalam memecahkan masalah yang ditemui serta adanya ketidak puasan hanya dengan jawaban yang benar tapi mereka ingin berbagi dan menjelaskan kepada orang lain bagaimana mereka menemukan jawaban tersebut.

Banyak hal yang dapat dilakukan dalam membentuk maupun mengukur kemampuan penalaran proporsional seseorang, salah satunya yaitu membuat berbagai macam produk, baik dalam permainan, pembelajaran maupun penilaian. Penelitian yang dilakukan oleh Sungmi yang berjudul Estimation games and proportional reasoning in young children menunjukkan bahwa, permainan estimasi dapat digunakan untuk menumbuhkan pengertian angka pada siswa kelas satu sampai dengan tiga yang ditempatkan dalam kategori yang mencerminkan tahap pengembangan penalaran proporsional. Selain itu, permainan estimasi ini tersebut juga memberikan kesempatan kepada anak untuk berfikir kritis tentang hubungan matematika dalam suasana yang menyenangkan dan interaktif (Ann-Kim, 2003).

Dalam mengembangkan kemampuan penalaran seseorang, tidak terlepas dari kemajuan zaman. Semakin majunya zaman, maka penalaran seseorang dituntut untuk dapat berkembang lebih baik lagi. Selain itu, interaksi manusia kepada lingkungan disekitarnya juga dapat berpengaruh pada kemampuan penalaran proporsionalnya. Hal ini didukung oleh penelitian yang dilakukan oleh Higino, Carlos \& Lena yang dilakukan kepada sekelompok anak bahasa 
Italia menunjukkan bahwa keterlibatan matematika siswa dikembangkan sebagai proses relasional yang ditandai hubungan sosial siswa dari waktu ke waktu yang mengacu pada aspek aktivitas sosial dan budaya (Dominguez, Lópezleiva, \& Khisty, 2014).

Peneliti menyadari bahwa dalam proses penelitian dan pengembangan model penilaian kemampuan penalaran proporsional ini terdapat beberapa keterbatasan. Pertama, pada proses pengembangan model yang merujuk pada model pengembangan Borg and Gall, tidak semua langkah dilakukan. Proses diseminasi dan implementasi tidak dapat dilakukan karena peneliti mengalami kesulitan dalam biaya dan waktu untuk mengembangkan model tersebut lebih lama lagi sehingga berdampak pada kurang memuaskannya pada implementasi model dalam skala yang lebih luas. Kedua, uji coba soal memerlukan waktu yang cukup lama karena peneliti tidak mampu mendapatkan hasil tes kepada responden dalam jumlah banyak dengan sekali uji coba.

Melihat dari penjabaran keterbatasan dalam penelitian tersebut diatas, selanjutnya peneliti akan membahas beberapa kelebihan serta kekurangan dari model penilaian tersebut. Adapun kelebihan dan kekurangan dari model penilaian dapat ditinjau dari dua aspek, yaitu kualitas soal dan penggunaan.

Pada aspek kualitas soal, produk penilaian ini memiliki beberapa keunggulan, yaitu pertama butir-butir soal sudah melalui tahap analisis butir yang telah disesuaikan dengan variabel serta tingkat kesukaran dan daya pembeda soal sudah teruji. Kedua, produk ini telah melalui proses telaah pakar, sehingga perbaikan dan saran dari expert judgement sangat membantu untuk mengembangkan soal yang diharapkan. Ketiga, jika dilihat dari Taksonomi Bloom, model ini tidak hanya mengukur pengatahuan (C1) dan pemahaman (C2) namun juga dapat mengukur bidang lainnya, seperi kemampuan penalaran (C3), analisis (C4), sintesis (C5) hingga evaluasi. Dari segi penggunaan, model ini dapat digunakan untuk membantu mengukur kemampuan penalaran proporsional pada mahasiswa calon guru sekolah dasar awal.

\section{KESIMPULAN}

Guru belum memiliki produk penilaian khusus untuk mengukur berfikir tingkat tinggi mahasiswa, khususnya dalam aspek proporsional. Model penilaian ini akan dapat membantu guru untuk mengukur tinggi rendahnya kemampuan yang dimiliki mahasiswa, sehingga guru dapat memberikan rangsangan agar setiap aspek yang ada pada penalaran proporsional dapat tercapai dengan baik yang nantinya akan menunjang keberhasilan anak dalam berfikir tingkat tinggi dalam kehidupan selanjutnya. Berdasarkan hasil uji coba yang dilakukan pada mahasiswa PGSD strata satu di Universitas Negeri Jakarta terbukti secara efektif bahwa model penilaian yang dikembangkan dapat mengukur kemampuan penalaran proporsional yang dimiliki oleh mahasiswa dalam mata kuliah konsep dasar biologi.

\section{DAFTAR PUSTAKA}

Ann-Kim, S. (2003). Estimation games and proportional reasoning in young children, 5.

Arifin, Z. (2011). Evaluasi Pembelajaran. Bandung: Remaja Rosdakarya.

Arvyati, C. S. (n.d.). Pengaruh Model Pembelajaran Berbasis Masalah (PBM) terhadap kemampuan Penalaran Proporsional Siswa Sekolah Pertama. Pendidikan Matematika.

Bakker, A., Groenveld, D., \& Wijers, M. (2014). Proportional reasoning in the laboratory: an intervention study in vocational education, 211-221. 
https://doi.org/10.1007/s10649-0129393-y

Ceneida Fernandez, Salvador Llinares, Wim, Vandooren, Dirk De Bock, L. V. (2011). EFFECT OF NUMBER STRUCTURE AND NATURE OF QUANTITIES ON SECONDARY SCHOOL STUDENTS ', (2005), 6982.

Dahar, R. W. (2011). Teori-teori Belajar dan Pembelajaran. Jakarta: Erlangga.

David benchaem, James T. Fey, William M. Fitzgerald, Catherine Benedetto, J. M. (1998). Proportional reasoning among 7th grade student curricular experiences. Educational Studies in Mathematics, 36, 247-273.

Desmita. (2007). Psikologi Perkembangan. Bandung: PT Remaja Rosdakarya.

Dominguez, H., Lópezleiva, C. A., \& Khisty, L. L. (2014). Relational engagement: Proportional reasoning with bilingual Latino / a students, 143160. https://doi.org/10.1007/s10649013-9501-7

Fah, L. Y. (2009). Logical Thinking Abilities among Form 4 Students in the Interior Division of Sabah , Malaysia, 32, 161-187.

Gabriela, V. dan E. C. (2012). Prospective Elementary School Teachers Proportional Reasoning. PNA 7, 1-19.

Hilton, A., Hilton, G., Dole, S., \& Hilton, A. (2016). Promoting middle school students ' proportional reasoning skills through an ongoing professional development programme for teachers, 193-219.

https://doi.org/10.1007/s10649-0169694-7

Jamaris, M. (2006). Perkembangan dan Pengembangan Anak Usia Taman Kanak-kanak. Jakarta: Grasindo.

Kathleen Westrich, C. B. (2011). Villi , Villi Everywhere: Biological Structures , Surface Area, \& Proportional Thinking J J J Science Content \& Proportional Science Content , Proportional, 73(3), 156161.

https://doi.org/10.1525/abt.2011.73.3.7
Kingston, J. A., \& Lyddy, F. (2013). Self-ef fi cacy and short-term memory capacity as predictors of proportional reasoning. Learning and Individual Differences, 26, 185-190. https://doi.org/10.1016/j.lindif.2013.01 .017

Lesh, R., Post, T., dan Behr, M. (1988). Proportional Reasoning Number Concepts and Operations on the Middle Grades. Journal of Rston Lawrence Erlbaum \& National Council of Teachers of Mathematics.

Mardapi, D. (2007). Teknik Penyusunan Instrumen Tes dan Non Tes. Yogyakarta: Graha Ilmu.

Möhring, W., Newcombe, N. S., \& Frick, A. (2015). Journal of Experimental Child The relation between spatial thinking and proportional reasoning in preschoolers, 132, 213-220. https://doi.org/10.1016/j.jecp.2015.01. 005

Nur, A. S., \& Rahman, A. (2013). Mathematics Problem Solving as a Medium to Develop a Formal Reasoning at Student of Junior High School, II(I).

Robichaux-davis, R. R. (n.d.). pad doubling Lily pad doubling: Proportional reasoning development, 73(2), 13-24.

Spinillo, A. G., \& Bryant, P. (1991). Articles Children ' $\mathrm{s}$ Proportional Judgments : The Importanee of', Half , 427-440.

Walle, J. A. (2008). Pengembangan Pengajaran Matematika Sekolah Dasar dan Menengah. Jakarta: Erlangga. 